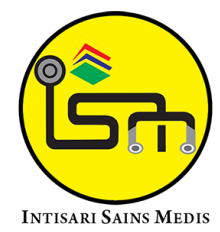

Published by Intisari Sains Medis

\section{Nilai rasio neutrofil-limfosit sebagai prediktor kasus COVID-19 serangan berat pada pasien dewasa}

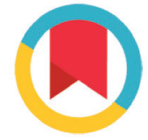

CrossMark

I Gusti Agung Ayu Sri Pramita Pramana ${ }^{1 *}$, Putu Utamia Suma Masyuni², I Dewa Putu Surawan³

\section{ABSTRACT}

Background: The pandemic condition that has been experienced since 2020 due to Coronavirus Disease (COVID-19) is still a national and international problem that needs full attention with number of cases continues to grow over time. Most cases of COVID-19 are cases with mild clinical manifestation, but some of these mild cases might then worsen in a matter of days due to the widespread inflammatory process that occurs due to viral infection. The use of NeutrophilLymphocyte Ratio (NLR) values in general has been known for its function as a biomarker of systemic inflammatory status. Therefore, this study is expected to be able to predict the incidence of severe COVID-19 in adult patients in BRSUD Tabanan, Bali.

Methods: The study was conducted using secondary data from 137 adult COVID-19 patients at BRSUD

Keywords: adult patients, NLR value, severe COVID-19.

Cite This Article: Pramana, I.G.A.A.S.P., Masyuni, P.U.S., Surawan, I.D.P. 2021. Nilai rasio neutrofil-limfosit sebagai prediktor kasus COVID-19 serangan berat pada pasien dewasa. Intisari Sains Medis 12(2): 530-533. D0I: 10.15562/ ism.v12i2.1093

\section{ABSTRAK}

Pendahuluan: Kondisi pandemi yang telah dialami sejak tahun 2020 akibat Coronavirus Disease (COVID-19) masih merupakan masalah nasional dan internasional yang perlu perhatian penuh dengan jumlah kasus yang terus bertambah seiring berjalannya waktu. Sebagian besar kasus COVID-19 merupakan kasus dengan keluhan ringan namun tidak sedikit kasus ringan tersebut kemudian dapat mengalami perburukan dalam hitungan hari akibat proses inflamasi luas yang terjadi karena infeksi virus. Penggunaan nilai rasio neutrofil-limfosit atau Neutrofil-Lymphocyte Ratio (NLR) secara umum telah diketahui fungsinya sebagai biomarker status inflamasi sistemik. Oleh karena itu, melalui penelitian ini diharapkan mampu memprediksi kejadian COVID-19 serangan berat pada pasien dewasa di BRSUD Tabanan.

Metode: Penelitian ini merupakan penelitian
Tabanan in June - December 2020. The sampling method used was consecutive sampling of all adult patients aged 18 years who had been diagnosed with COVID-19 and treated in the isolation room.

Results: There were 61 cases (44.5\%) of severe COVID-19. Of 88 cases of COVID-19 with NLR $>3.3,56$ cases (63.6\%) were classified as severe COVID-19 and of 49 cases of COVID-19 with NLR 3.3 only 5 cases (10.2\%) were classified as severe COVID-19. Patients with NLR values $>3.3$ were found to have 6.2 times as likely to suffer from severe COVID-19 than patients with 3.3 NLR values.

Conclusion: The NLR value as one of the easy and simple tests can be used to predict the incidence of severe COVID-19 in patients. observasional dengan rancang penelitian crosssectional analitik menggunakan data sekunder dari 137 pasien dewasa COVID-19 di BRSUD Tabanan bulan Juni - Desember 2020. Metode sampling yang digunakan adalah consecutive sampling terhadap seluruh pasien dewasa usia $\geq 18$ tahun yang telah terdiagnosis COVID-19 dan dirawat di ruang isolasi.

Hasil: Ditemukan sebanyak 61 kasus (44,5\%) tergolong kasus COVID-19 serangan berat. Dari 88 kasus COVID-19 dengan NLR $>3,356$ kasus $(63,6 \%)$ tergolong kasus COVID-19 serangan berat dan dari 49 kasus COVID-19 dengan NLR $\leq 3,3$ hanya 5 kasus (10,2\%) tergolong kasus COVID-19 serangan berat. Pasien dengan nilai NLR > 3,3 ditemukan memiliki risiko 6,2 kali lebih besar menderita keluhan COVID-19 serangan berat dibandingkan pasien dengan nilai $N L R \leq 3,3$.

Simpulan: Nilai NLR sebagai salah satu pemeriksaan
1,2Dokter Umum, Badan Rumah Sakit Umum Daerah Tabanan, Bali;

Umum Daerah Tabanan, Bali;

\section{*Korespondensi:}

I Gusti Agung Ayu Sri Pramita Pramana; Dokter Umum, Badan Rumah Sakit Umum Daerah Tabanan, Bali;

pramitapramana@yahoo.com

Diterima: 19-05-2021

Disetujui: 25-07-2021

Diterbitkan: 06-08-2021 
mudah dan sederhana dapat digunakan untuk beratpadapasien. memprediksi lebih awal terjadinya COVID-19 serangan

Kata kunci: COVID-19 serangan berat, nilai NLR, pasien dewasa.

Sitasi Artikel ini: Pramana, I.G.A.A.S.P., Masyuni, P.U.S., Surawan, I.D.P. 2021. Nilai rasio neutrofil-limfosit sebagai prediktor kasus COVID-19 serangan berat pada pasien dewasa. Intisari Sains Medis 12(2): 530-533. D0I: 10.15562/ ism.v12i2.1093

\section{PENDAHULUAN}

Pada bulan Maret 2020, World Health Organization (WHO) mengumumkan adanya kondisi pandemik yang disebabkan oleh penyebaran penyakit infeksi Coronavirus Disease (COVID-19). Penyakit ini disebabkan oleh virus Severe Acute Respiratory Syndrome Coronavirus-2 (SARS-CoV-2). Kasus COVID-19 pertama kali ditemukan di Wuhan, Hubei, China dengan manifestasi klinis berupa pneumonia berat hingga menyebabkan penderitanya dapat jatuh ke dalam kondisi Acute Respiratory Distress Syndrome (ARDS) ${ }^{1,2}$ Indonesia termasuk salah satu negara yang terdampak akibat penyebaran COVID-19 ini, dengan kasus pertama ditemukan pada Maret 2020. COVID-19 telah menyebabkan hingga lebih dari 1 juta kematian di Indonesia dan 44.000 kasus per April 2021 ditemukan di provinsi Bali. ${ }^{3}$

Nilai neutrofil-limfosit atau NeutrofilLymphocyte Ratio (NLR) secara umum telah diketahui fungsinya sebagai biomarker status inflamasi sistemik. Penelitian yang telah dilakukan sebelumnya menyebutkan bahwa NLR merupakan alat prediktor yang sederhana, mudah ditemukan, dan efektif untuk memprediksi derajat keparahan pasien COVID-19. Meta analisis yang telah dilakukan sebelumnya juga menyebutkan bahwa pasien COVID-19 serangan berat memiliki nilai NLR yang lebih tinggi dibandingkan dengan pasien COVID-19 serangan tidak berat. Selain itu didapatkan nilai NLR yang lebih tinggi pada pasien COVID-19 serangan berat yang tidak selamat dibandingkan dengan COVID-19 serangan berat yang sembuh sehingga NLR dapat digunakan sebagai prediktor mortalitas pada pasien COVID-19 serangan berat. ${ }^{4,5}$ Oleh karena itu, penelitian ini bertujuan untuk menganalisis penggunaan NLR sebagai prediktor terjadinya COVID-19 serangan berat pada pasien dewasa.

\section{METODE}

Penelitian ini dilakukan di Badan Rumah Sakit Umum Daerah (BRSUD) Tabanan yang merupakan rumah sakit tipe $B$ dan merupakan salah satu RS rujukan COVID-19 sejak awal pandemi tahun 2020. ${ }^{6}$ Penelitian ini merupakan penelitian observasionaldengan rancangan penelitian cross-sectional analitik menggunakan data sekunder dari rekam medis pasien. Metode sampling yang digunakan adalah consecutive sampling terhadap seluruh pasien dewasa usia $\geq 18$ tahun yang telah terdiagnosis COVID-19 dan dirawat di ruang isolasi COVID-19 BRSUD Tabanan pada bulan Juni-Desember 2020.

Variabel tergantung penelitian ini adalah COVID-19 serangan berat yang memenuhi salah satu dari ketentuan sesuai buku pedoman tatalaksana COVID-19 Edisi 3 dan juga disebutkan dalam artikel ilmiah internasional lain, yaitu: (1) frekuensi napas $>30 \mathrm{kali} / \mathrm{menit}$, (2) $\mathrm{SpO} 2<93 \%$ pada udara ruangan dan kriteria tambahan yaitu (3) distres napas berat/ARDS/gagal napas, syok, atau tanda kegagalan organ lain. ${ }^{7-9}$ Variabel bebas adalah nilai NLR berdasarkan hasil pemeriksaan laboratorium yang pertama kali dilakukan saat pasien dirawat. Nilai NLR hasil pembagian nilai neutrofil dengan limfosit dalam bentuk nilai absolut atau persentase. Nilai NLR dikategorikan sebagai berisiko (NLR > 3,3) dan tidak berisiko $(\leq 3,3)$.

Faktor predisposisi atau prediktor dianalisis menggunakan tabulasi silang faktor prediktor (NLR) dengan kasus COVID-19 serangan berat, didasarkan pada nilai Prevalence Ratio (PR) dari masing-masing prediktor. Analisis bivariat yang digunakan adalah uji Chi-
Square dengan tingkat kemaknaan 5\%. Pengolahan data menggunakan aplikasi Statistical Package for the Social Science version 21 (SPSS ver. 21). Penelitian ini sudah mendapatkan layak etik dari Komite Etik Penelitian Kesehatan (KEPK) Kabupaten Tabanan, Bali dengan nomor 070/3143/IZIN-C/DISPMPT.

\section{HASIL}

Pada hasil penelitian didapatkan dari 137 kasus COVID-19, sebanyak 61 kasus $(44,5 \%)$ tergolong kasus COVID-19 serangan berat. Kejadian COVID-19 lebih banyak didapatkan pada jenis kelamin laki-laki pada sebanyak 82 orang $(59,9 \%)$ dan sebanyak 55 orang $(44,1 \%)$ didapatkan pada perempuan. Kasus COVID-19 pada pasien dewasa didapatkan terjadi pada rentang usia $20-89$ tahun (mean value $51,96 \pm$ SD 14,69). Nilai NLR pasien COVID-19 didapatkan dengan nilai NLR terendah 1,1 dan tertinggi 68,9 dengan rata-rata nilai NLR 7,398.

Hasil uji statistik pada penelitian ini menunjukkan adanya pengaruh antara pasien dengan nilai NLR > 3,3 memiliki risiko 6,2 kali lebih besar menderita keluhan COVID-19 serangan berat dibandingkan pasien dengan nilai NLR $\leq$ $3,3$ (IK 95\%= 2,6-14,5; P-value $<0,001)$. Hasil kalkukasi mendapatkan bahwa dari 88 kasus COVID-19 dengan nilai NLR > 3,3, didapatkan 56 kasus (63,6\%) tergolong sebagai kasus COVID-19 serangan berat. Sedangkan, dari 49 kasus COVID-19 dengan nilai NLR $\leq 3,3$, hanya 5 kasus $(10,2 \%)$ yang tergolong sebagai kasus COVID-19 serangan berat (Tabel 1).

\section{PEMBAHASAN}

Dari hasil penelitian didapatkan pasien dengan nilai NLR > 3,3 berisiko lebih besar dibandingkan dengan nilai NLR $\leq 3,3$. Pasien-pasien dengan COVID-19 


\begin{tabular}{cccc}
\hline \multirow{2}{*}{ Kategori NLR } & \multicolumn{2}{c}{ Kategori Serangan COVID-19 } & Total \\
\cline { 2 - 3 } & Berat & Tidak Berat & \\
\hline Berisiko $(>3,3)$ & $56(63,6 \%)$ & $32(36,4 \%)$ & $88(100 \%)$ \\
Tidak Berisiko $(\leq 3,3)$ & $5(10,2 \%)$ & $44(89,8 \%)$ & \\
Total & $61(44,5 \%)$ & $76(55,5 \%)$ & \\
\hline
\end{tabular}

Keterangan: $\mathrm{PR}=6,2$ (IK 95\%: 2,6 - 14,5) $\mathrm{X}^{2}=36,380, \mathrm{P}<0.001$

serangan berat umumnya didapatkan dengan neutrofilia dan limfopenia akibat terjadinya proses inflamasi luas yang merupakan mekanisme patofisiologi utama yang terjadi pada COVID-19. Pada kondisi ini akan didapatkan neutrofil yang tinggi dan limfosit yang rendah sehingga menghasilkan nilai hitung neutrofil banding limfosit yang tinggi dan umumnya sesuai dengan tingkat keparahan serangan COVID-19. ${ }^{1,5,8}$ Penelitian yang dilakukan Ding, dkk. menemukan nilai limfosit jauh lebih rendah pada pasien serangan berat saat awal masuk rumah sakit dan cenderung sulit untuk pulih dan sembuh selama masa perawatan. Selain itu juga ditemukan hubungan NLR dengan tingkat keparahan penyakit dengan NLR yang jauh lebih tinggi pada pasien COVID-19 serangan berat. ${ }^{8}$

Wang, dkk. pada penelitiannya mendapatkan bahwa nilai NLR 3,328 memiliki nilai prediktif yang baik dalam memprediksi kejadian mortalitas pada pasien COVID-19 dengan sensitivitas $100 \%$ dan spesifisitas $84 \%$. Nilai NLR juga mampu memprediksi progresivitas penyakit selama pasien dirawat inap di rumah sakit serta berhubungan dengan lama rawat di rumah sakit. ${ }^{5}$ Sejalan dengan hasil penelitian Yang, dkk. yang mendapatkan nilai batas optimal penggunaan NLR sebagai alat prognostik kemungkinan perubahan serangan COVID-19 ringan menjadi berat adalah dengan nilai NLR 3,3. Temuan yang juga disebutkan yaitu pasien COVID-19 usia $>$ 49,5 tahun dengan serangan tidak berat dan nilai NLR > 3,3 harus mendapatkan observasi yang lebih ketat karena sekitar $46,1 \%$ dari kelompok pasien ini didapatkan kemudian mengalami serangan berat setelah rata-rata 6,3 hari perawatan di rumah sakit. ${ }^{9}$ Eslamijouybari, dkk. juga mendapati adanya hubungan nilai NLR dengan derajat berat serangan COVID-19 pada pasien, dimana didapatkan nilai NLR yang lebih tinggi pada pasien dengan COVID-19 serangan berat. Namun terdapat sedikit perbedaan pada penelitian ini yang menggunakan batas nilai NLR > $3,1 .^{2}$

Penelitian ini memiliki beberapa keterbatasan, salah satunya adalah keterbatasan jumlah sampel dan hanya dilakukan pada pasien dewasa. Penelitian ini hanya dilakukan di satu rumah sakit rujukan COVID-19, sehingga penelitian ini belum bisa digeneralisasi untuk semua kasus COVID-19. Pada penelitian ini tidak dilakukan observasi lebih jauh pada perjalanan penyakit pasien dan tidak dilakukan perbandingan antara NLR pada saat pasien awal dirawat dengan selama masa perawatan di rumah sakit. Namun, penelitian ini dapat menjadi dasar dan acuan penelitian lanjutan mengenai penggunaan NLR sebagai prediktor terjadinya COVID-19 serangan berat pada pasien dewasa, dan memungkinkan pada pasien anak-anak atau lansia. Pengembangan penelitian selanjutnya mengenai nilai NLR juga dapat dilakukan dengan memasukan variabel lain seperti penyakit penyerta pasien. Diharapkan melalui hasil penelitian ini pula dapat membantu tenaga kesehatan untuk memprediksi derajat keparahan kondisi pasien dan membantu penentuan tatalaksana pasien selanjutnya dengan lebih optimal.

\section{SIMPULAN}

Nilai NLR merupakan pemeriksaan yang sederhana dan mudah ditemukan serta efektif untuk memprediksi lebih awal terjadinya COVID-19 serangan berat pada pasien sehingga bila diperlukan dapat meningkatkan kewaspadaan dalam tatalaksana pasien selanjutnya.

\section{UCAPAN TERIMA KASIH}

Terima kasih ditujukan kepada keluarga, teman-teman, dan banyak pihak di Badan Rumah Sakit Umum Daerah (BRSUD) Tabanan Bali yang telah membantu kelancaran penelitian ini.

\section{KONFLIK KEPENTINGAN}

Semua penulis yang terlibat menyatakan tidak terdapat konflik kepentingan (conflict of interest) pada penulisan laporan penelitian ini.

\section{PENDANAAN}

Semua penulis yang terlibat bertanggung jawab terhadap seluruh pembiayaan dalam pembuatan laporan penelitian ini.

\section{KONTRIBUSI PENULIS}

Semua penulis yang terlibat bertanggung jawab dalam pembuatan dan penulisan laporan penelitian ini.

\section{DAFTAR PUSTAKA}

1. Susilo A, Rumede M, Pitoyo CW, Santsoso WD, Yulianti M, dkk. Coronavirus Disease 2019: Tinjauan Pustaka Terkini. Jurnal Penyakit Dalam Indonesia. 2020; 7 (1): 45-67.

2. Eslamijouybari M, Heydari K, Maleki I, Vahedi L, Hedayatizadeh-Omran A, Vahdei L, dkk. Neutrophil-to-Lymphocyte and Platelet-toLymphocyte Ratios in COVID-19 Patients and Control Group and Relationship with Disease Prognosis. Caspian J Intern Med. 2020; 11 (suppl1): 531-535.

3. Gugus Tugas Nasional Percepatan Penanganan COVID-19 Kemenkes RI [Situasi COVID-19 Indonesia] [updated 2021; cited 2021 April 30]. Available from: https://bnpb-inacovid19.hub. arcgis.com.

4. Chan AS, Rout A. Use of Neutrofil-toLymphocyte and Platelet-to-Lymphocyte Ratios in COVID-19. J Clin Med Res. 2020; 12(7): 448453.

5. Wang X, Li X, Shang Y, Wang J, Zhang X, Su D, dkk. Ratios of Neutrophil-to-Lymphocyte and Platelet-to-Lymphocyte Predict all-cause Mortality in Inpatients with Coronavirus Disease 2019 (COVID-19): a Retrospective Cohort Study in a Single Medical Center. Epidemiology and Infection. 2020; 148 (211): 1-8.

6. Kemenkes Republik Indonesia 2020 [Daftar 100 Rumah Sakit Rujukan COVID-19 di Indonesia]. [cited 2021 April 30]. Available from: https://infeksiemerging.kemkes.go.id/ download/Daftar RS rujukan COVID-19. pdf. 
7. Burhan E, Susanto AD, Nasution S, Pitoyo CW, Susilo A, Firdaus I, dkk. Pedoman Tatalaksan COVID-19. Edisi 3. Jakarta: Tim Penerbit PDPI, PERKI, PAPDI, PERDATIN, IDAI; 2020.

8. Ding X, Yu Y, Lu B, Huo J, Chen M, Kang Y, Lou J, Liu Z. Dynamic Profile and Clinical
Implications of Hematological Parameters in Hospitalized Patients with Coronavirus Disease 2019. Clin Chem Lab Med. 2020; 58(8): 13651371.

9. Yang A, Liu J, Tao W, Li H. The Diagnostic and Predictive Role of NLR, d-NLR, and
PLR in COVID-19 Patients. International Immunopharmacology. 2020; 84:106504.

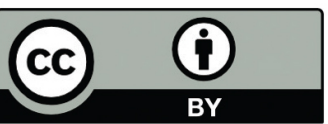

This work is licensed under a Creative Commons Attribution 